\title{
AIRBORNE INFECTION WITH MYCOBACTERIUM LEPRAE IN MICE
}

\author{
R. J. W. Rees AND A. C. MCDougall* \\ National Institute for Medical Research, London, NW7 1AA, and Department of Human \\ Anatomy, University of Oxford, Oxford OX1 $3 Q X$
}

Although our bacteriological and pathological studies on the nose in patients with lepromatous leprosy (Davey and Rees, 1974; McDougall et al., 1975) underline the importance of nasal secretions as a major source of Mycobacterium leprae in the transmission of leprosy, they do not necessarily clarify the route of infection. However, patients whose nasal mucus is loaded with $M$. leprae might be expected to produce and to project infected aerosols and droplets during talking, coughing and sneezing. Similarly, M. lepraeinfected particles from shed and dried nasal secretions in handkerchiefs or on the ground could become airborne. A comparison of the modes of spread and incidence of pulmonary tuberculosis and leprosy (Rees and Meade, 1974) in comparable populations in South India has indicated that the attack rates for the two diseases in family or household contacts are similar, as are also the numbers of $M$. tuberculosis excreted in sputum and of $M$. leprae excreted in nasal discharges by patients with pulmonary tuberculosis and lepromatous leprosy respectively (Rees and Meade, 1974). Thus it was reasonable to consider a respiratory route of infection for leprosy, and the present study was undertaken to determine whether mice were susceptible to airborne infection with $M$. leprae.

\section{MATERIALS AND METHODS}

The present larger scale experiment was based on results obtained in 1967 when one of us (R. J. W. R.) was investigating the different routes for infecting mice with $M$. leprae. By airborne infection the only three mice successfully infected were killed 15-23 months after exposure to $M$. leprae; unfortunately the 17 other mice exposed to infection had been killed earlier and all were negative. Therefore in the present study the outcome of airborne infection was confined to mice killed 14 months or more after exposure to $M$. leprae.

\section{Methods for production of and exposure to airborne infection}

The apparatus used was based on that described by Henderson (1952) and Druett and May (1952), modified for 10 mice at a time to be exposed to clouds of dry bacteria-containing particles of $1-2 \mu \mathrm{m}$ diameter. In this apparatus, only the head of the mouse is exposed to the infective cloud.

The physical conditions of the apparatus for the delivery of clouds containing M. leprae were adjusted to those that had been established for the quantitative delivery of known numbers of viable particles of $M$. tuberculosis reaching the lungs of mice (S. Peacock, personal communication). It was estimated that the lung retention per mouse was $7 \mathrm{ml}$ of the bacteria-containing cloud per min. and that from a reservoir containing $5 \times 10^{6}$ viable units of $M$. tuberculosis per $\mathrm{ml}$, a cloud of $1 \times 10^{4}$ viable units per litre per min. was produced. Therefore the average rate of lung challenge with $M$. tuberculosis per mouse was 70 viable

Received 14 May 1976; accepted 13 July 1976. $7 \mathrm{JH}$.

* Present address: Department of Dermatology, The Slade Hospital, Headington, Oxford OX3

J. MED. MICROBIOL.-VOL. 10 (1977) 
units per min. Under these same conditions the whole-head challenge per mouse was estimated to be $4 \mathrm{ml}$ per min., i.e., 40 viable units of $M$. tuberculosis per min. Although no data are available for the anatomical distribution of the bacilli within the head of the mouse, a proportion could have been retained in the nasal passages.

\section{Preparation and standardisation of $M$. leprae for airborne infection}

The pilot study in 1967 indicated that mice could be systemically infected with $M$. leprae by airborne infection that gave a lung retention of $1 \times 10^{5}$ bacteria. Therefore, from the data for $M$. tuberculosis with the Henderson apparatus, it was calculated that a lung retention of $1 \times 10^{5} \mathrm{M}$. leprae per mouse would require a cloud-exposure time of $60 \mathrm{~min}$. from a spray suspension containing $1.2 \times 10^{8} M$. leprae per ml. From this, the whole-head retention of $M$. leprae was calculated to be $5.7 \times 10^{4}$. To avoid tiring the mice, they were given six separate $10-\mathrm{min}$. exposures to the $M$. leprae cloud.

The suspension of viable $M$. leprae was obtained from biopsies of skin from four patients with active and previously untreated lepromatous leprosy. The bacteria were extracted from skin by homogenisation in $0.1 \%(\mathrm{w} / \mathrm{v})$ bovine albumin in water, followed by differential centrifugation, and the concentration of $M$. leprae determined by measuring the number of acid-fast bacilli (AFB) by the methods of Rees (1964). The suspensions were pooled and diluted to yield $45 \mathrm{ml}$ of $M$. leprae in $0.1 \%$ bovine albumin in water containing $1.2 \times 10^{8} \mathrm{AFB}$ per $\mathrm{ml}$. The morphological index (mean percentage of solidly-stained bacilli on ZiehlNeelsen staining) of the bacteria was 10 , indicating a $10 \%$ viability (Rees, 1965).

Samples of $M$. leprae from the pooled suspension, before and after use in the Henderson apparatus, were inoculated at a concentration of $1 \times 10^{4}$ AFB into both hind foot pads of six mice in order to determine and compare their respective viabilities.

\section{Assessment and sampling of mice}

Six-week-old female CBA mice were used in all the experiments. For the main airborne infection, 48 mice previously immunologically suppressed by thymectomy followed 2 weeks later by five exposures to irradiation $\left(200 \mathrm{R}{ }^{60} \mathrm{Co}\right)$ at fortnightly intervals were used, since such mice (" $T / R$ mice") were more susceptible to infection with $M$. leprae than normal animals (Rees, 1966). Immediately after exposure to aerosols of $M$. leprae, five mice were killed and their lungs and nose tips individually homogenised for enumerating AFB. Mice dying less than 14 months after aerosol exposure were discarded, but from then onwards remaining mice were killed, or those that died were dissected, taking from each both ears, foot pads and right and left lungs separately and the nose tip. All of the tissues taken from dying mice were homogenised and the AFB content determined; from a proportion of the killed mice, tissues from all representative sites were subjected to AFB counts and some of the duplicate samples were also examined histologically, as was a deeper part of the nasal tissue.

Normal, not $T / R$, mice were used for determining by foot-pad inoculation the viability and growth characteristics of the bacteria prepared for the airborne infection and of bacteria harvested from the lung, ear or nose of three individual mice 16,17 or 22 months, respectively, after airborne infection. For each of these assessments, $1 \times 10^{4} \mathrm{AFB}$ were inoculated into the hind foot pads of six mice, and the yield of AFB per foot pad determined in individual mice killed from each group 5 months after inoculation and at monthly intervals thereafter (Rees, 1964).

\section{Results}

\section{Viability of $M$. leprae used for airborne infection}

There was no quantitative difference in the rate or pattern of growth of $M$. leprae in mice after foot-pad inoculation of $1 \times 10^{4} \mathrm{AFB}$ from the reservoir of $M$. leprae sample before and after completion of the airborne infection. 
TABLE

Recovery of Mycobacterium leprae by site and yield of acid-fast bacilli (AFB) 14-24 months after expsoure of 30 mice to airborne challenge with $10^{5} \mathrm{M}$. leprae organisms

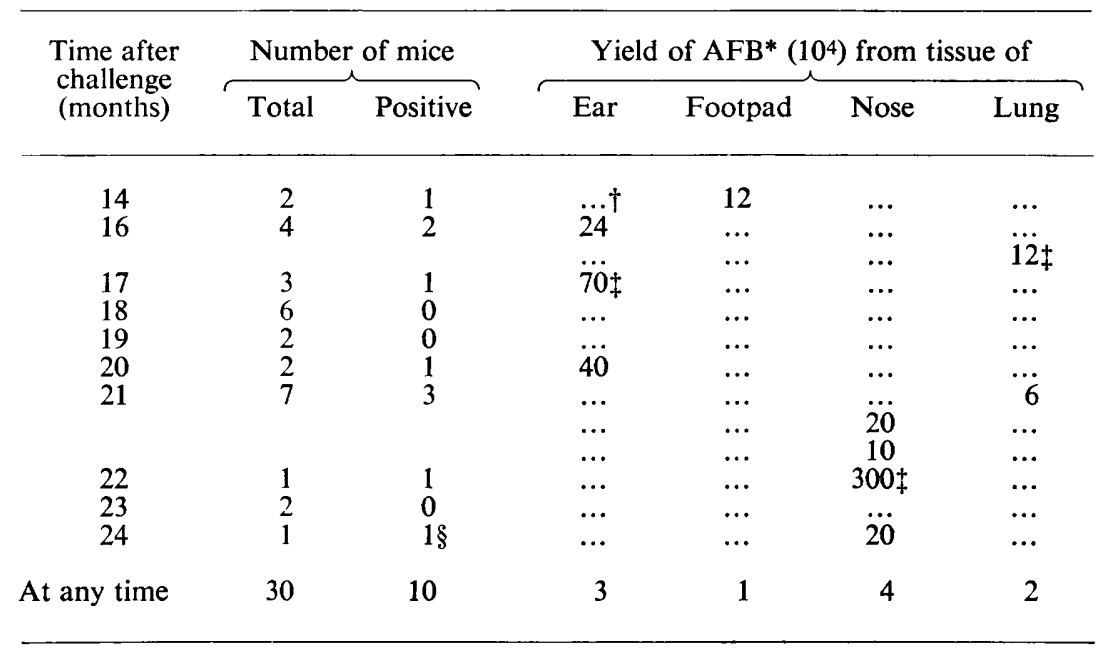

* $\mathrm{AFB}=$ acid-fast bacilli; counts given are in tens of thousands.

$\dagger$ Yield $<2 \times 10^{4}$.

$\ddagger$ Multiplication observed when inoculated into foot pad of normal mice.

$\S$ AFB also present in bone marrow from femurs.

\section{Retention of $M$. leprae in the lung and nose}

Of the five mice killed immediately after exposure to airborne infection with $M$. leprae, the individual AFB counts on homogenates from the whole lungs were $36,8.4,6,3.2$ and $<2 \times 10^{4}$ respectively, whereas no AFB $\left(<2 \times 10^{4}\right)$ were counted in homogenates from the noses of any of the five animals.

\section{Airborne infection with M. leprae}

Because the earlier pilot experiment had failed to show systemic infection in mice until 15 months after airborne infection with $M$. leprae, no mice from the present experiment were examined before 14 months post-infection. At 14 months, 30 of the original 43 were alive and all of these as they died or were killed in the ensuing 10 months (i.e., up to 2 years after exposure) were examined for AFB in homogenates from their ears, foot pads, nose and lungs. From the results summarised in the table it can be seen that $33 \%$ (10 of 30$)$ of the mice had countable numbers of AFB $\left(>2 \times 10^{4}\right)$ at one or more of the sites. The AFB morphologically resembled $M$. leprae. Although only an isolated observation, it is of interest that in the last surviving mouse killed 24 months after aerosol exposure, at a time when the bone marrows of $M$. leprae-infected mice were being examined as a routine, AFB were seen in the pooled marrow suspension from both femurs in addition to the countable AFB yield from a foot pad.

None of the other representative tissues of this last mouse showed convincing histological evidence of $M$. leprae infection. 
AFB harvested from a lung, ear and nose of three individual mice, respectively 16, 17 and 22 months after airborne infection, multiplied when inoculated at a dose of $1 \times 10^{4}$ into the foot pads of normal mice. Moreover, their rates and patterns of multiplication were similar to those of $M$. leprae.

\section{DISCUSSION}

These results have established that immunologically suppressed $(T / R)$ mice can be infected with $M$. leprae by airborne infection, thus confirming the evidence from an earlier and smaller experiment. Although a different type of apparatus for producing the infection was used in the two studies, both were based on a lung retention of $1 \times 10^{5} \mathrm{M}$. leprae. The Henderson apparatus as used in the present study, was adjusted to expose only the head of the mouse to clouds of dry bacteria-containing particles of 1-2 $\mu \mathrm{m}$ diameter, which favours lodgement in the lung rather than in the nose. The infecting dose of $1 \times 10^{5} \mathrm{M}$. leprae was obtained by using the apparatus under conditions established in quantitative pulmonary infections with $M$. tuberculosis. This proved to be satisfactory, for a mean lung retention of $1 \cdot 1 \times 10^{5} \mathrm{M}$. leprae (counted as AFB) was obtained from five mice killed immediately after airborne infection. Under the same conditions the total head retention of $M$. tuberculosis was $57 \%$ of that retained in the lung, giving a calculated total head retention for $M$. leprae of $5 \cdot 7 \times 10^{4} \mathrm{AFB}$. In fact, none of the nasal tissues from the same five mice sampled immediately after airborne infection yielded countable AFB's $\left(<2 \times 10^{4}\right)$; thus the nasal tissues retained $<35 \%$ of the calculated total head retention of $M$. leprae.

It seems that within the murine respiratory tract the main lodgement of $M$. leprae is in the lungs, making this site the probable portal of entry. However, the nose is not completely excluded as a portal of entry; nor is the gastrointestinal tract excluded as a secondary portal for $M$. leprae swallowed by the mice. Such bacteria might initially be held in nasal secretions or might be carried up from the lung via the trachea or licked off the head. However, there is no direct evidence that the gastro-intestinal tract in the mouse is a portal of entry for $M$. leprae, since no animals have become infected when fed with suspensions of $M$. leprae by stomach tube (R. J. W. Rees, unpublished data).

Fourteen to 24 months after airborne infection with $M$. leprae, small but significant numbers of AFB were harvested from selected sites in 33\% (10 of 30) of the mice. Identification of these AFB as $M$. leprae was based on their morphological characteristics, their inability to multiply in conventional mycobacterial media and the rate and pattern of growth in the mouse foot pad of inocula from three of the animals exposed to $M$. leprae aerosol.

The unusually long incubation period and small proportions of animals infected after aerosol exposure suggest that only small numbers of viable $M$. leprae have escaped from the lungs, probably via blood or lymphatic vessels, and subsequently came to rest at sites favourable for their multiplication. After airborne infection of 10 mice, four had significant numbers of $M$. leprae in the nose and three in the ear. These favoured sites for multiplication of M. leprae after airborne infection are also favoured after intravenous 
inoculation or systemic spread from foot pad inoculation of $M$. leprae (Rees, McDougall and Weddell, 1974). This suggests that infection in the nose, as in the ear, arises from systemic spread rather than from small numbers of $M$. leprae retained during the airborne infection.

The importance of the nose and nasal secretions in leprosy, although noted long ago (Goldschmidt, 1891; Sticker, 1897; Schäffer, 1898), attracted little comment until Muir (1921; 1929) and Browne (1966) drew attention to its clinical and epidemiological significance. Pedley (1973) described the enormous numbers of apparently viable bacilli issuing from the nasal cavity of untreated lepromatous patients, and emphasised the rarity of bacilli on the intact skin surface (Pedley, 1970). Histopathological studies of the septum and turbinates (Job, Karat and Karat, 1966; McDougall et al., 1975) have amply confirmed the density of bacilli in these tissues, the numerous routes of escape of bacilli from the stroma into the nasal cavity, and the high morphological index of the many bacilli seen in sections. Despite all this, there is no direct evidence that the nose is a portal of entry in either lepromatous or non-lepromatous forms of the disease. Indeed, with the doubtful exceptions of intra-nasal infections with staphylococci and with Klebsiella rhinoscleromatis in man, there are no known bacteria that enter and also initiate a primary chronic infection in the nose, in man or in animals. However, by analogy with tuberculosis and with the epidemiological evidence already quoted (Rees and Meade, 1974), the lung is a likely portal of entry in leprosy. Nevertheless, involvement of the lung in clinically established lepromatous leprosy has never been convincingly described in patients, and only rarely in post-mortem material (Junarkar, 1957; K. V. Desikan, personal communication). On the other hand, in the thymectomised-irradiated mouse (Rees et al., 1967) and in the armadillo (Kirchheimer, Storrs and Binford, 1972), lung parenchyma is indeed involved after experimental infection with $M$. leprae from man. This suggests that further studies should be undertaken on the lungs of patients with lepromatous leprosy. Meanwhile from the positive results of our studies in the mouse, we conclude that leprosy in man may also result from an airborne infection entering through the lung, although other routes of infection are not excluded.

\section{SUMMARY}

Although the portal of entry and mode of spread of $M$. leprae in human leprosy are still uncertain, it is widely held that direct person-to-person skin contact is important. This assumption has ignored the fact that patients with highly bacilliferous leprosy have nasal as well as dermal infection and that, since $M$. leprae is shed predominantly from the nose, leprosy might be an airborne infection. The present study was designed to investigate this possibility with mice exposed to airborne infection with $M$. leprae. The conditions are described in which thymectomised-irradiated CBA strain mice exposed to $M$. leprae aerosols sustained an immediate lung retention of $1 \times 10^{5}$ bacteria. Fourteen to 24 months later, $33 \%$ (10 of 30 ) of the mice had countable numbers of acid-fast bacilli $\left(>2 \times 10^{4}\right)$ with the characteristics of $M$. leprae in one or more homogenates prepared from ears, foot pads, nose or lungs. Evidence 
is presented from the distribution of $M$. leprae that the infection had arisen from systemic spread of bacilli initially entering the lungs rather than from multiplication of organisms locally retained there, or in the nose, at the time of airborne infection. The relevance of these results to the possible route of infection of leprosy in man is discussed.

We are indebted to Mr S. Peacock, Division of Aerobiology, Microbiological Research Establishment, Porton, Wiltshire, for his technical advice, and to Professor R. J. Olds, Department of Pathology, Cambridge University, for undertaking the earlier airborne infection with $M$. leprae. A. C. McD. was supported by grants from the Medical Research Council and the British Leprosy Relief Association (LEPRA).

\section{REFERENCES}

Browne, S. G. 1966. The value of nasal smears in lepromatous leprosy. Int. J. Lepr., $34,23$.

Davey, T. F. AND ReEs, R. J. W. 1974. The nasal discharge in leprosy; clinical and bacteriological aspects. Lepr. Rev., 45, 121.

Druett, H. A. AND MaY, K. R. 1952. A wind tunnel for the study of airborne infections. J. Hyg., Camb., 50, 69.

GolDSCHMIDT, J. 1891. Der nasale Ursprung der Lepra. In Die Lepra auf Madeira, Leipzig, p. 200.

Henderson, D. W. 1952. An apparatus for the study of airborne infection. J. Hyg., Camb., 50, 53.

Job, C. K., KARAT, A. B. A. AND Karat, S. 1966. The histopathological appearance of leprous rhinitis and pathogenesis of septal perforation in leprosy. J. Lar. Otol., 80, 718.

JunNarkar, R. V. 1957. Late lesions in leprosy. Lepr. India, 29, 148.

Kirchheimer, W. F., Storrs, E. E. AND Binford, C. H. 1972. Attempts to establish the armadillo (Dasypus novemcinctus Linn.) as a model for the study of leprosy. II. Histopathologic and bacteriologic post-mortem findings in lepromatoid leprosy in the armadillo. Int. J. Lepr., 40, 229.

McDougall, A. C., Rees, R. J. W., Weddell, A. G. M. and Kanan, M. Wadji. 1975. The histopathology of lepromatous leprosy in the nose. J. Path., 115, 215.

MuIR, E. 1921. Handbook on leprosy. Its diagnosis, treatment and prevention. Cuttack, India.

Muir, E. 1929. Leprosy, diagnosis, treatment and prevention. 5th ed., Delhi, p. 53.

Pedley, J. C. 1970. Composite skin contact smears: a method of demonstrating the nonemergence of Mycobacterium leprae from intact lepromatous skin. Lepr. Rev., 41, 31.

Pedley, J. C. 1973. The nasal mucus in leprosy. Lepr. Rev., 44, 33.

REES, R. J. W. 1964. Limited multiplication of acid-fast bacilli in the foot pads of mice inoculated with Mycobacterium leprae. Br. J. exp. Path., 45, 207.

ReEs, R. J. W. 1965. Recent bacteriologic, immunologic and pathologic studies on experimental human leprosy in the mouse foot pad. Int. J. Lepr., 33, 646.

ReEs, R. J. W. 1966. Enhanced susceptibility of thymectomized and irradiated mice to infection with Mycobacterium leprae. Nature, Lond., 211, 657.

Rees, R. J. W., Waters, M. F. R., Weddell, A. G. M. ANd Palmer, E. 1967. Experimental lepromatous leprosy. Nature, Lond., 215, 599.

Rees, R. J. W. AND Meade, T. W. 1974. Comparison of the modes of spread and the incidence of tuberculosis and leprosy. Lancet, $1,47$.

Rees, R. J. W., McDougall, A. C. AND Weddell, A. G. M. 1974. The nose in mice with experimental human leprosy. Lepr. Rev., 45, 112.

SCHÄFFER, J. 1898. Ueber die Verbreitung der Leprabacillen von den oberen Luftwegen aus. Archs Derm., 44, 159.

STICKer, G. 1897. Mittheilungen über Lepra nach Erfahrungen in Indien and Aegypten. Münch. med. Wschr, 44, 39, 1063. 